\title{
Bridging the Gap in Human Relations through the Novel: A Reflection on Houénou Kowanou's les Enfants de la Poubelle
}

\author{
Irene Udousoro, $\mathrm{PhD}$ \\ (Associate Professor), Department of Foreign Languages, \\ PMB 1017, University of Uyo Uyo, Nigeria \\ Email: iudousoro@yahoo.com
}

\section{Doi:10.5901/mjss.2014.v5n20p2475}

\begin{abstract}
Even in this present ICT age, the novel still serves as an effective tool of communication. The setting of the novel selected for this study, Houénou Kowanou's Les Enfants de la poubelle, cuts across three continents: America, Europe and Africa. The heroine, Madeleine, provides an opportunity for the researcher to study human beings and their response to human suffering and pain. Issues like single parenting, kidnapping, child abuse, racial prejudices, underdevelopment, etc. are examined using the psychoanalytical approach, focusing on trauma studies. Through the concept of the universality of suffering and pain as depicted by the heroine's experiences in the three continents she traverses, attempt is also made to suggest how posttraumatic experiences could be handled and better human relations could be achieved. Suggestions would also be made on how to possibly bridge gaps among peoples of diverse societies through lessons learnt via the novel in perspective with a view to ensuring and enhancing global peace.
\end{abstract}

Keywords: Human relations, sociological approach, trauma studies

\section{Introduction}

Man's existence, well-being and survival are anchored on relationships, more specifically on interpersonal relationships. Relationships make or mar individuals. They help individuals to develop a sense of self or make them deteriorate to a point of wanting to annihilate self. The family, being the foundation of human existence and relationships, has a vital role to play in an individual's life, and generally, in human development. Psychologists, sociologists, social workers, etc. are all involved in the study of social and interpersonal relationships as a means of understanding human beings and their behaviors, and in particular, vis-à-vis other people. Novelists have, through their narratives or creative works, also played a major role in the study of human relationships and their incidence on an individual's personality. An interpersonal relationship could be summarized as a strong or close association between two or more people formed in the context of social, cultural and other influences which may vary from family/kinship relations, friendship/marriage to other social considerations. Disciplines such as sociology, psychology, social work, etc. are interested in the study of interpersonal relations.

Houenou Kowanou's novel, Les Enfants de la poubelle, is a beautiful creative work on human or interpersonal relations. It is a story of traumatic suffering arising from failed relationships and the response of the traumatized individuals, particularly the protagonist, Madeleine, to the stimulus of suffering and pain. The major character is a victim of circumstances who finds herself always moving away from either happiness or pain and never really finding a lasting fulfillment wherever she sojourns. In America, her home country, in Europe and then in Africa where she flees to in an attempt to escape her mother's wrath and vengeance, Madeleine is constantly trailed and tracked down by suffering and pain. Les Enfants de la poubelle is more or less a traumatic testimony intended perhaps, by the author of the novel to make the reader to explore with the traumatized character but eventual trauma survivor a way of transcending suffering.

This paper examines the various relationships the major character, Madeleine, had in the novel and how they affected her life positively or negatively, thereby causing her pain. To discuss this, issues like single-parenting, sexual abuse, racial prejudice, etc. come into focus as major sources of trauma. The trauma sufferer is marked psychically and physically by the traumatic events she experiences and that informs our choice of the psychoanalytic theoretical framework focusing on trauma studies in this work. Apart from identifying the gaps in relationships leading to trauma, we intend to suggest how these gaps could be bridged so as to ensure better interpersonal or human relations and intergroup adjustments. 


\title{
2. The Single Parent Family Phenomenon
}

The traumatic events narrated in Les Enfants de la poubelle obviously have their roots in the single parent phenomenon. By focusing his literary lens on the heroine, Madeleine, a child raised in a single parent family headed by a mother as primary caregiver, the author, Houénou Kowanou engages the reader in an intellectual debate on the social and psychological problems that this family situation engenders. The single parent phenomenon is fast becoming a trend and a norm in the society irrespective of development indices or stratifications. A child born and raised in this kind of family situation often comes under much pressure. Madeleine clearly feels 'different' from her peers and falls out with her mother, Gabrielle, over her dating and entering new relationships. In the introduction of the novel, the reader gets to know about Madeleine's state of mind vis-à-vis the single parent family type. In her own words:

\begin{abstract}
Je suis issue d'une famille monoparentale. Pour tout parent, je n'ai connu que ma mère. Et je n'en deviens consciente qu'au moment où, à la maternelle, mes copines parlèrent de pères, de frères et de tantes. (...) A quoi peut donc ressembler une vie à plusieurs, je n'en sus rien pendant longtemps. Un fleuve de joie ou plutôt un festival de désolations? J'ai dû passer plus de temps que de jours d'enfance à vouloir le savoir. Pendant des années, ce fut le sujet majeur de ma vie, une sorte d'obsession maladive à laquelle je cherchais une réponse decisive. Des copines servirent à ma curiosité leurs histoires de famille...
\end{abstract}

\begin{abstract}
I was born into a single parent family. I only knew my mother as a parent. I only became conscious of it when, in the nursery school, my friends talked about fathers, brothers and aunties (...) What does it look like having a large family? I had no idea for a very long time. An ocean of joy, or rather, a festival of desolations? I must have spent more time than my childhood days trying to get the answer. For many years, it was a major issue of my life, a kind of sickening obsession for which I was seeking a decisive answer. Friends fed my curiosity with stories about their families...
\end{abstract}

It is expected that even a single parent should provide emotional support, nurturing and protection for the child he or she raises. Absence of these provisions can have negative effects on the child's/person's personality ranging from low self-esteem to trauma. Psychologists and advocates are of the opinion that single parenting has adverse mental, emotional and psychological implications on the child. This is clearly Madeleine's case as we shall discover in her relationship with other characters as well as her experiences throughout the novel.

\section{Trauma as Product of Failed Relationships}

\section{According to Rosanne Kennedy (1997:237):}

\begin{abstract}
In recent years, scholars from a range of disciplines have drawn on psychoanalysis to explore the implications that traumatic events (both personal and collective) have for individual and collective memory, and for practices of cultural and historical representation. A good deal of this work, developed by scholars working in the United States and Canada, focuses on the Holocaust, the bombing of Hiroshima, the spread of AIDS, childhood sexual abuse...
\end{abstract}

On the literary scene, the foremost and frontline African writer, Chinua Achebe, cited by Ângela Lamas Rodrigues (2007:1), sees his writings as "re-storying peoples who had been knocked silent by the trauma of all kinds of dispossession". This view, for us, summarizes the nature and character of traumatic writings as they relate to literature. The introduction of Les Enfants de la poubelle, novel written by Houénou Kowanou (2000), exposes the psychoanalytic thrust of the novel. The heroine, Madeleine, reveals her traumatic experiences in these terms:

\begin{abstract}
Je ne prétends pas que ma démarche parmi les hommes constitue une expérience digne de mémoire. (...). Je ne décrocherai donc pas la merveille en parlant de moi. Seulement, dans les conditions de femme usagée qu'aujourd'hui je suis, je me vois presque menacée de démence. Mille regrets dans mes souvenirs cruels font surgir mon enfance et me donnent envie d'en parler à quelqu'un, un lecteur inconnu par exemple (p.4).
\end{abstract}

I do not claim that my approach among men is an experience worth remembering. (...). I will not achieve a feat talking about myself. Just that as an old and worn-out woman that I am today, I feel almost threatened with dementia. A thousand regrets in me conjure up painful memories of my childhood and make me want to talk to someone, to an unknown reader, for example.

Arising from the above confession by the heroine, one could view the novel being studied as act of witnessing to the traumas of failed relationships, Trauma then is an appropriate psychoanalytical vocabulary to describe Madeleine's 
experiences. A girl raised by a single mother who ought to enjoy her mother's emotional support, nurture and protection is sexually abused, at the age of eighteen by a man who is her mother's bed mate and who has been "engaged" by her mother to rape her. Madeleine gets pregnant after the rape and is thrown out into the street by her mother. She is kidnapped while wandering in the streets and suffers physical and emotional trauma in the hands of her abductors. Madeleine is a victim of circumstances. She does not understand why her mother hates her so much and wants to destroy her.

Providentially, Madeleine, through the sympathy and help of the leader of the kidnappers, Pigeon Bleu, travels to France where she hopes to be free from her mother's wrath and vengeance. While in France, she gets married to an unnamed journalist who is more interested in his job than in spending time with his wife and always tries to make up for this inadequacy with expensive gifts. Madeleine's experience in marriage is far from being fulfilling. She confesses that 'Dans le foyer... il m'aimait plus que je ne l'aimais' (p.118). According to Madeleine, her husband loved her more than she loved him. To overcome boredom, she went on holiday alone, was raped in her hotel room, and eventually was thrown back into the street by her husband on account of infidelity.

After series of experiences that make Madeleine take to drinking and even contemplate suicide as a way out of pain and suffering, she again providentially, through a relationship with a certain Robert who repeatedly exploits her sexually on his terms, moves to Africa where there seems to be a ray of hope that she has finally found true love and joy. The heroine gets married to a crowned prince, Aloya, and gives birth to two sons. In order to be well integrated into the African community which is revealed in the novel as the Republic of Benin, Madeleine is initiated into witchcraft and receives tribal marks all over her body. Tragedy soon strikes the Aloya family as they lose their second son because the witches and wizards claim Madeleine failed to carry out one of her designated functions as a queen. Madeleine is terribly hurt by her son's death and decides to go back to Dallas with her first son, 'Le vieux', so as to forget the death of her second son, Kiki.

This situation is aptly captured by a female psychologist, (...) cited by Rosanne Kennedy (1997) in these terms:

\begin{abstract}
In a study of human responses to death, psychoanalyst Louise Kaplan suggests why the loss of a child represents a tragedy for the parent: 'The urge to generate a new life that is a reflection of one's own life stems from a profound desire to extend one's own existence, to be and to become something more and better than one actually is. When a parent loses a child, this mirror of her own value and power is gone forever' (p.239)
\end{abstract}

For Madeleine, Africa had offered her love and seemed to have been a compensation for her experiences of rejection, suffering and pain but through the loss of her son had given her a dose of pain which she could not withstand. Moving away from where she had lost a part of herself, a treasure and going back to Dallas was obviously a palliative for her pain. Clearly, Madeleine was repeatedly denied the power to form and maintain human relationships. First, her mother sent her away from home because both mother and daughter were sharing lovers because the mother was morally bankrupt. Then her husband sent her away because he felt she was unfaithful to him. Later she left Aloya when she lost her son in Africa. Finally, she lost her first and surviving son mysteriously in Dallas. She just woke up one morning and discovered that her son had disappeared without any trace and was never found again.

The heroine's story and experiences are woven primarily around her relationships with her mother, her husband in France and then her husband, Aloya in Africa. These relationships were the major causes of pain and trauma in her life. It is in Africa however, that the heroine discovers true relationships which are however not perfect. In spite of the love, warmth and affection the heroine experienced with her husband and with members of the extended family and the community as a whole, she found out that pain and suffering seem to be part of human existence. What hurts most is when pain and suffering are caused by very close family members and associates.

\title{
4. Racial Prejudice as Source of Trauma
}

In sociology, racism or racial prejudices refer to abusive or aggressive behavior towards members of another race on the basis that some races have intrinsic superiority over others. This results in or explains hatred or intolerance of another race. Prejudice is defined as "an aversive or hostile attitude toward a person who belongs to a group simply because he belongs to that group and is therefore presumed to have the objectionable qualities ascribed to that group" (Coser, 1991, p.278).

In the novel, Les Enfants de la poubelle, the most striking case of racial prejudice is experienced by the heroine at the airport in Madrid, Spain. In an attempt to 'belong' in the African community where Madeleine had 'migrated' to, she had received some tribal marks (scars) on her face, some tattoo marks on her body, etc. On their return trip to America 
and at the airport in Madrid where they were waiting for a connecting flight, mother and child were mocked and taunted by a group of young travellers because of their physical appearance and colour. Some of these young people even tried to take photographs of Madeleine and her son. Madeleine had a full dose of embarrassment and pain because of this inhuman treatment and had to make a super-human effort not to use her witchcraft powers to punish her detractors. According to her, "Certaines phrases étaient très amères pour moi". The dialogue below paints a picture of racial prejudice in very cruel terms:

\author{
-Dans quelles forêts est-elle allée se promener? \\ -Pour ramener un fauve? \\ -On dirait un lion (...) \\ -Elle aurait été violée par des animaux, sans doute! \\ -Elle a poussé des griffes! \\ -Elle n'est plus blonde! \\ -Elle a perdu son charme! \\ -Et quels sont ces tatouages? \\ -Moi, je n'aime pas ces tâches noires! \\ -Il lui faudra des cures de dermato!
}

The boys, obviously whites, displayed racist tendencies towards Madeleine and her son through open use of foul language (presuming that the heroine and her son did not understand what they were saying). Referring to the duo as 'fauve' (wild animals), wondering from which forêt (forest) (country) they were coming with 'griffes' (claws), etc. suggests that the young boys do not know much or anything about the continent called Africa. They may have been sincerely wrong in their judgments about Madeleine and her son. Their reaction towards the heroine and her son may have been caused by an inner impulse driven by curiosity. The only problem was that they did not know that voicing out their inner questionings and curiosity would amount to racial prejudice and offend their target listeners. Good reasoning demands that one should give other people one meets on the way (where there is no established relationship) some respect because one may not know where they are coming from or the pain they are going through. Besides, other peoples' culture should not be trivialized. According to Joseph Charles (2005:33), "Anthropologists should come up with theories and probably evolve general laws that could explain cultural phenomena in human society. It is then that the similarities and differences in cultures could be put in proper perspectives and ethnocentric feelings subdued..." Madeleine's reaction to the young boys' taunting reveals the neurotic state of her personality. Neuroticism is a personality trait defined by Deary and Mathews, cited by Michael Armstrong (2006: 242) as having the following characteristics: anxiety, depression, hostility, self-consciousness, impulsiveness, vulnerability. Like in other situations, faced with the boys' taunting and inhumane treatment, Madeleine though vulnerable and very hurt, endured the emotional trauma and moved on.

\title{
5. Identifying and Bridging Gaps in Human Relationships
}

Read as traumatic testimony, the novel, Les Enfants de la poubelle brings to focus issues of single parenting, sexual abuses, kidnapping, racial prejudices, etc. which constitute the major sources of pain and trauma to Madeleine. Ordinarily, the mother-daughter relationship ought to be founded on love. Gabrielle, Madeleine's mother, was bound by duty and natural laws to provide security for her daughter and inculcate good moral values into her. She however could not give what she did not have. The gap in this mother-daughter relationship was the reason for all the woes Madeleine experienced in her life: she was thrown into street life, was raped several times, experienced a failed marriage in Europe, tried to commit suicide and finally remarried in Africa and gave birth to two children but lost both in the long run.

Gabrielle had a change of heart towards her daughter at the end of the novel when she reappears in Africa and the daughter begs her to pardon her for whatever crime she had committed that created enmity between them. This plea goes right into Gabrielle's heart and brings about a profound change of heart in her. The once evil and malicious mother finally decides to forgive her daughter. She tries to compensate her daughter for all the traumatic experiences she had been through by giving her property and a lot of money to have a fresh and proper start in life. This gesture represents an attempt to bring about healing through the love of a mother. The way then to bridge the gap in the mother-daughter relationship is for both parties to forgive wrongs and make amends in whatever way they can or deem necessary.

Marriage is another level of relationship that can either bring fulfillment or pain to either party or both partners. Coming from a single parent family background, Madeleine may have had hopes of being fulfilled in marriage. However, her unnamed Caribbean husband is self-centered and lacks maturity. Inviting his parents home to settle his family 
disputes is a mark of irresponsibility and weakness and is very demeaning. No woman would be comfortable with that kind of interference in private family matters. This first marriage crashes and Madeleine is sent away by her husband for reasons of infidelity which was partly her husband's fault. Madeleine, the ousted child and wife moves on with pain in her heart and soul. The reader has the impression that Madeleine's Caribbean husband is a kind of parenthesis in her life or a channel through which she migrates to Africa, a place where she experiences love and acceptance bringing about healing and temporary relief from her feeling of rejection and the resultant pain.

Madeleine's first husband thus contributes to her suffering and pain. Undoubtedly, a failed marriage is most likely to cause emotional, psychological and even physical trauma to either of the parties involved or both parties. Any marriage where there is no love or security particularly for the woman considered as the weaker sex is not likely to succeed. Madeleine's first husband represents those who have misplaced values and priorities as far as marriage is concerned, Money and gifts are important in marriage but one's commitment should be all-embracing. The gap between husbands and wives could be bridged if both parties learn to be considerate and accommodating and put the other person's interest above profession or job or other personal concerns.

Still seeking for happiness and healing from rejection, Madeleine gets married in Africa to Aloya who is kindness, sincerity and gentleness personified. According to Madeleine, he is the only man who truly loves her. Madeleine's second marriage is like a fairy tale. Aloya is like a compensation for Madeleine for the trauma she has experienced in past relationships with men. Aloya's love gives Madeleine the will and the strength to live in a rural African community. Marriage to Aloya brings healing to Madeleine's hurts.

However, Aloya is not a superhuman or faultless. He believes in their African tradition to a fault. When their second son dies and Madeleine feels hurt, he tells her that they should have had ten children so that if they lost three of them, they would still have some left! That was wry humour and a very bad one for a mother who had lost a son. At other times, Madeleine enjoyed her husband's sense of humour but this was a very painful joke in the face of this devastating loss.

When finally Madeleine decides to go back to Dallas, she still treasures Aloya and habours no bitterness in her heart for him. Aloya loved Madeleine, cared for and protected her while she was in Africa and willingly let her go back to America so that she could recover from the pain of their son's death. The Aloya-Madeleine couple seems a perfect one; the only thing that came between them was the African tradition that killed their child. Words can heal and can also kill. In relating with one another, couples should learn to weigh their words before they voice them out. That seems to be one of the lessons one learns from the relationship between Madeleine and Aloya.

With regard to racial prejudice, the heroine's adventures in America, Europe and Africa are an opportunity for the reader to get to 'meet' with people, though fictional, in these three continents. The reader gets to know that no matter how developed a country may be, there are things and people that undermine and violate other people's rights thereby causing them pain. There are also some countries of the world considered as underdeveloped where one can find true love but also pain. There is no perfect human society. Madeleine's sojourn in these three continents reveals the universality of pain and could best be described as a journey towards self-actualization pitched with sufferings and pain and punctuated with fugitive moments of joy. Madeleine knows love, hate and flirts with the idea of suicide a number of times as a way out of pain. That has been the bane of millions of people the world over who have experienced trauma as a result of physical affliction, hate, loss of loved ones, deprivations, family disintegrations, personal or national disasters, oppression, etc.

In order to bridge gaps in human relationships across borders, one needs to, like Madeleine in Les Enfants de la poubelle, have an open mind towards other peoples' cultures, which have the potential of making one's dreams to be actualized. One should come to terms with the fact that there are cultural diversities. No one race should see their culture as being superior to another. One should learn to appreciate other peoples' cultures and imbibe those that respond to their inner drives towards self-actualization. For instance, in the case of the African culture, it is posited that "the African cultures cum practices are unique, useful and rich. There are inherent values that can be extracted from the day to day activities or practices of the indigenous African society. The richness of the practices lies in their functionality and roles in the human and societal development" (Omotosho, 2013, p.54). Disregarding or worse still, mocking another person's culture or cultural identity is bound to cause disharmony and conflicts which are inimical to global peace.

Racial prejudices could be addressed and controlled through information dissemination as well as through travels and interactions through seminars, conferences and workshops, etc. One observes that certain documentary films on some developing countries, for instance, focus on wildlife more than on the developmental strides recorded by these countries. It is our belief that if the technological advancements as well as achievements recorded by these countries are projected to the world, these countries would be appreciated and even respected globally. On their part, developing countries should handle their security challenges effectively and ensure that basic infrastructural facilities are put in place in order to attract investors and facilitate exchange programs among students from other countries of the world, 
particularly the developed ones. This would open up their communities to the outside world and promote interpersonal and intercultural exchanges which ultimately ensure and promote global peace.

Another issue that recurs in the novel, Les Enfants de la poubelle, and which traumatizes the heroine, Madeleine, is rape or sexual violence. In America, Europe and in Africa (in Africa, Robert, a companion of circumstances from Europe, is the perpetrator of this vile act vis-à-vis Madeleine), the heroine is a victim of sexual abuse. This societal ill could be decisively dealt with if perpetrators are apprehended by law enforcement officers and disgraced publicly. Their pictures should be posted on internet so that they are ridiculed locally and internationally. This would act as a deterrent to other social misfits. This view is confirmed by W. Thomas (1972:71) who affirms that negative sanctions such as ridicule, fines or imprisonment should be applied to those people who do not conform to social or group norms in order to compel them and others to do so.

\section{Towards Post-Trauma Healing and Rehabilitation}

At the end of her adventures in America, Europe and Africa, the protagonist in Les Enfants de la poubelle, Madeleine, concludes that she is "une femme usagée", presque menacée de démence, "pratiquement tombée comme une feuille d'automne". These metaphors of being "worn out", "threatened by dementia" and "practically fallen like a leaf in autumn" are as a result of the traumatic experiences she had. Clearly, her ego was wounded and the only way to lessen the pain is to talk about it to someone else, a ready and willing listener who ends up sharing the pain.

Madeleine dedicates her writing to all the oppressed children the world over, that is, "Les enfants de la poubelle". This is because "many children are denied basic education, a good standard of living and their fundamental human right to dignity and freedom..." (Olubunmi, 2010, p.494) Reaching out to help others through her testimony is a way of receiving healing and also healing others. The novel, Les Enfants de la poubelle, should be seen in that light- a testimony of a personal trauma intended to heal others with similar traumatic experiences. Literature, therefore, and in particular Les Enfants de la poubelle, is expected to perform a healing function. Readers are expected to be healed of emotional, psychological or social challenges through the reading of a text. With adventures such as the ones shared by Madeleine in the novel read, the reader is able to participate imaginatively with the protagonist and can gain new ideas and knowledge.

\section{Conclusion}

From our reading of Les Enfants de la poubelle, it is evident that relationships are crucial to human existence, survival and development. The family is the primordial foundation to human relationships and development. A child who grows up in an atmosphere of antagonism with either of his or her parents who acts as the primary care-giver is most likely to have traumatic experiences that make him or her a pathological adolescent and eventual adult. The study of the protagonist of the novel examined has been very revealing. Madeleine, coming from a dysfunctional family background, becomes a victim of rape, kidnapping, failed marriages, racial prejudice, etc. This paper has been an attempt to examine how the heroine has been traumatized by these experiences and how her trauma testimony can be a source of healing for her and for others with similar experiences.

The ultimate aim of this paper has been to identify gaps in human relationships and to suggest ways of bridging them because "... a deeper understanding of human relations, both in cultural and historical contexts, is more necessary than ever before to prevent conflicts" (Ademuyiwa, 2010, p.555). It is our belief that this paper will inspire individuals to set up Non-Governmental Organizations that can educate youths on safety mechanisms aimed at protecting them from all forms of abuses and harassments. Apart from enacting and enforcing laws that will protect their citizenry, governments of developed and developing countries as well as public-spirited individuals and NGOs should establish institutions and organizations charged with the responsibility of organizing tours of countries in different parts of the world. This will make it possible for people to familiarize themselves with the cultures of other peoples thereby reducing the incidence of racial prejudices. This could also attract some investors to some parts of the world visited. Some "Big Brother" countries could decide to register their presence in other countries stratified as underdeveloped or developing and help deal with underdevelopment in such countries that definitely need foreign aid. This would go a long way in bridging gaps through reducing the poverty line in these economically deprived countries.

Finally, there are many Madeleines the world over who are waiting to be healed of the effects of their traumatic experiences through our genuine friendship or trauma testimonies and we hope this paper is a modest contribution in that direction. 


\section{References}

Ademuyiwa, A. (2010). The Roles of Culture and Nationalism in the Task of Nation Building in Europe. In Emmanuel Kwofie \& Babatunde Ayeleru (Eds.), Language, Literature and Civilization, Ibadan: Zenith Book House, 533-555.

Armstrong, M. (2006). A Handbook of Human Resource Management Practice- 10 th Edition, United Kingdon: Kogan Page.

Brown, M. (2008). Screams Somehow Echoing: Trauma, and Testimony in Anglophone African Literature (Ph.D Thesis).

Charles, J. (2005). Social Anthropology- Concept, Theory and Ethnography, Lagos: Serenity Publishers.

Coser, L. A., et al. (1991). Introduction to Sociology, New York: Harcourt Brace Jovanovich Publishers.

Kennedy R. (1997). The narrator as Witness: Testimony, Trauma and Narrative Form in My Place, Meridan, 16(2), 235-260.

Kowanou, H. (2000). Les Enfants de la poubelle, Porto-Novo: Les Editions HDH.

Olubunmi, R. (2010). "A Review of Modern Child Abuse, Neglect and Nation Building: An Example of the Nigerian Society" (in Language, Literature and Civilization- Essays in honour of Professor Aduke Adebayo- Ed. Emmanuel Kwofie and Babatunde Ayeleru), pp 533-555.

Omotosho, C. (2013). The Educational Values of African Traditional Practices. In A. D. Akoh \& S. E. Inegbe (Eds.), Arts, Culture and Communication in a Postcolony, Kent, United Kingdom: Alpha Crown Publishers, 48-57.

Rodrigues, A. (2007). The Trauma of a Diminished Existence: Chinua Achebe revisited, Postcolonial Text, 3(4),1-23.

Thomas, W. L. \& Anderson, R. J. (1972) Sociology: The Study of Human Relationships, New York: Harcourt Brace Jovanovich Publishers, Inc. 